\title{
A filmes merchandising megjelenési formáinak, alkalmazhatóságának és történetének irodalmi vizsgálata
}

\author{
Horváth Ádám - Gyenge Balázs \\ Szent István Egyetem
}

\begin{abstract}
A TANULMÁNY CÉLJA
Manapság egyre gyakrabban találkozhatunk azzal a jelenséggel, hogy a filmek márkái és audiovizuális elemei már nem csak a mozitermek vásznairól köszönnek vissza, hanem a boltok polcairól is, különböző - filmekhez köthetö - termékek formájában. Ezt a jelenséget nevezzük merchandising-nak, vagyis arculatátvitelnek, amikor különböző termékeket és szolgáltatásokat kötnek össze eseményekkel, jelen esetben a filmek megjelenésével (ily módon összekapcsolva öket).

A tanulmány célja, hogy feltárja a filmes merchandising főbb jellemzőit; a különböző filmek esetében felhasznált arculati elemeket és azok megjelenési formáit, kialakulásuk előzményeit. Emellett vizsgálja a merchandising helyét a többi - filmek népszerüsítésére használt - eszköz között, illetve választ keres arra is, hogy mely kritériumoknak kell egy adott filmnek megfelelnie ahhoz, hogy alkalmazható legyen a merchandising; milyen különbségek fedezhetők fel a különálló filmek és a már bejáratott filmsorozatok („film univerzumok”) márkái között; illetve a film teljes életgörbéjének tükrében melyik szakaszban kerül erre a legnagyobb hangsúly. Végül kitekintést nyújt a filmekkel összekapcsolt termékek és szolgáltatások fogyasztói megítélésére és az ebben bekövetkezett esetleges változásokra is.
\end{abstract}

\section{ALKALMAZOTT MÓDSZEREK}

A tanulmányban alkalmazott módszertanként a szakirodalmi feldolgozást választottuk, összefoglalva a főbb elméleti megközelítéseket és összefüggéseket, valamint az elmúlt évek során zajlott fontosabb kapcsolódó kutatások eredményeinek feltárását.

\section{LEGFONTOSABB EREDMÉNYEK}

Kiemelhetjük a hosszú múlttal rendelkező merchandising iránt továbbra is növekvő érdeklődést. Itt külön meg kell említeni a Disney által folytatott merchandising tevékenységet, mely mind történeti, mind jelenlegi tevékenysége (a mai napig messze a legnagyobb fogyasztói termékekhez köthető licenctulajdonos) alapján a terület abszolút vezetójének számít. A pozitív eredmények mellett azonban mindenképpen meg kell jegyezni, hogy még a legnagyobb filmsorozatok, bejáratott címek esetében is láthatunk visszaesést a nézők számában, mely a merchandising időzítését is egyre inkább a biztosabban felmérhető otthoni megjelenés felé tolhatja.

\section{GYAKORLATI JAVASLATOK}

Gyakorlati javaslatunk elsősorban egy olyan empirikus kutatás elindítása, amelynek során vizsgálni lehetne a film és a kapcsolódó merchandising közötti kereszt-promóció minden aspektusát, valamint az utóbbi években növekvő jelentőséghez jutó digitális megoldásokat.

Kulcsszavak: merchandising, fogyasztói magatartás, filmfogyasztás

DOI: https://doi.org/10.15170/MM.2019.53.EMOK.07 


\section{BEVEZETÉS}

A merchandising fogalma három megközelítésben is értelmezhető: a merchandising mint kiskereskedelmi értékesítés (különösen nagy mennyiségü, gyorsan fogyó tömegcikkek értékesítése esetén); a merchandising mint folyamat (ideértve minden olyan tevékenységet, amely a termékek sikeres kiskereskedelmi bevezetésére irányul); illetve a merchandising mint a szellemi termékek tömegmarketingje. Ez utóbbi értelmezés része az „arculatátvitel” fogalma is, melynek során különböző szellemi alkotások (mint például televíziós sorozatok vagy mozifilmek) köré épített termékvonalakat alakítanak ki (Bereczkiné Farkas 2008). Az eljárás lényege, hogy a szellemi termékekből már jól ismert személyiségek, figurák, jelzések felhasználásával járulnak hozzá a reklámozó arculatának kialakításához. Ily módon - mivel az eredeti forrásokhoz már valamilyen pozitív tartalom kapcsolódik - ezek alkalmazása olyan alapbizalmat eredményez, amely könnyebben kelti fel az érdeklődést a reklámozott termék vagy szolgáltatás iránt (Barta - Szücs 2015). E tanulmányban a merchandising kifejezést a korábban említett harmadik - az ,arculatátvitel” fogalmát tartalmazó - értelmezés szerint alkalmazzuk.

Ha ilyen szemmel is figyeljük a filmipar termékeit, könnyedén tetten érhetjük, hogy ez az eljárás milyen jól múködik a filmek esetében. Az éppen müsoron lévő animációs filmek játékfigurái felbukkannak a gyorséttermek gyerekmenüiben éppúgy, mint a gabonapelyhes dobozokban. Megtalálhatók a különböző ruhadarabokon, könyvek vagy videojátékok formájában, vagy akár alapélelmiszerek csomagolásain. Gyakorlatilag teljes körü reklámhadjárattá alakítják a mozifilmeket, ahol már az az elsődleges cél, hogy a legszélesebb közönséget vonják be a fogyasztásba (Schreiber 2009). Ez a folyamat a kilencvenes évektől erősödött a ma látható szintre, azóta vált folyamatosan egyre hangsúlyosabbá a merchandising szerepe. Napjainkban a kapcsolt termékek értékesítése - hasonlóan más, filmekhez kötődő reklámozási eljárásokhoz, mint pl. a termékelhelyezések - már jelentős hatást gyakorol magára a filmkészítés folyamatára is. Ráadásul a befektetési hajlandóságon keresztül befolyásolja az aktuális filmtrendek alakulását is, hiszen a merchandising egy újabb fontos szempontja lett a megtérülési rátának (Tóth 2015).

Tanulmányunkban a filmes merchandising-ot mint a filmek kommunikációs eszközét vizsgáltuk (hasonlóan például a filmeken belül megjelenő termékelhelyezéshez), és eszerint figyeltük meg főbb jellemzőit. Felállított célkitüzéseink a következők voltak:

C1: A filmes merchandising előfordulási formáinak csoportosítása.

C2: A merchandising mint eszköz alkalmazhatóságának és előfeltételeinek vizsgálata - a kifejezetten erre a területre vonatkozó sikeresség tükrében.

C3: A merchandising fogyasztói megítélésének vizsgálata társadalmi szinten.

Az itt feltárt tapasztalatok és ismeretek eszközeként az irodalmi feldolgozást választottuk. Ez egyben egy olyan későbbi empirikus kutatás feltáró fázisát készíti elö, ahol a film megjelenik mind termékként (amikor konkrétan ráirányul a kommunikáció), mind külön kommunikációs eszközként (amikor a filmben rejlő lehetőségeket használják fel egyéb termékek népszerüsítésére).

\section{A MERCHANDISING FELHASZ- NÁLÁSI TERÜLETEI}

A merchandising jól alkalmazható és kimondottan hatékony az üzleti élet szinte minden olyan területén, ahol reklámokra van szükség. A különböző figurákat, híres személyeket, árujelzőket azonban sok esetben nem az eredeti rendeltetésüknek megfelelően használják fel, hanem árujelzőket képeznek a filmcímekből, a képzeletbeli- vagy valós személyek neveiből. A következőkben a merchandising leggyakoribb megjelenési formáit ismertetjük (Bereczkiné Farkas 2008).

\section{Szórakozást szolgáló áruk és szolgáltatások}

Japánban, Kínában, Franciaországban és természetesen az Egyesült Államokban nagyon népszerüek a minden korosztály számára szórakozást nyújtó Disney-parkok, Disney-karakterekkel és -attrakciókkal. New Yorkban városnéző buszkirándulás épül a Szex és New York sikerére, de említhetők itt olyan szórakozóhelyek is, mint a Columbo sörözó Budapesten (a filmsorozat címszereplöje után). Ugyanide sorolhatók az általában a filmekhez köthető egyéb adaptációk (könyvváltozatok, bizonyos idősebb korosztályt célzó videojátékok vagy filmzenék) is.

\section{Sportcikkek}

A sportszergyárak általában híres nemzetközi sportolókra és csapatokra alapozzák reklámtevékenységüket, időnként azonban filmekre is építenek. 
Ilyen volt például a Nike 2015-ös Vissza a Jövőbe fémjelzésű cipőire épített kampánya, de ide sorolhatók azok a termékek is, amelyek sport tematikájú filmekhez kapcsolódnak (mint például a Rocky, vagy a rajzfilm és sport összekapcsolását jelképező Space Jam).

\section{Ajándék és dísztárgyak}

Olyan dísztárgyak, szobrok, figurák és kiegészítők tartoznak ebbe a csoportba, amelyek jellemzően filmekhez köthetők és az idősebb korosztályt célozzák meg. A tavalyi ünnepi szezon Star Wars felhozatalát nézve, szinte bármit meg lehet találni benne: Star Wars mintájú karórát, telefontokot, elektromos borotvát, modellrepülőt, de akár sütéshez használatos kesztyüt és még számos meglepő terméket.

\section{Divat, ruházati cikkek}

A divatáru-kereskedelem területén Magyarországon az elsők között jelent meg filmre utaló névvel a Pretty Woman divatház (a jól ismert amerikai film után szabadon). A ruházati cikkeknél érdemes kiemelni az azokat ajánló személyek, gyártók és brandek jó hírét, mivel viselésük egyfajta demonstratív fogyasztásként is felfogható, így a fogyasztók számára is nagyobb jelentősége van annak, hogy mit vesznek fel.

\section{Gyermekáruk}

Ez a korosztály a merchandising népszerű célpontja. Az elsősorban gyermekek számára készült termékek között legfontosabbak a különféle játékfigurák, videojáték adaptációk, iskolai felszerelések, ruházati cikkek, élelmiszerek. Ez utóbbi esetben gondolhatunk akár a mesefilmekhez kötött csokoládékra, a Kinder-tojás figurákra, de akár az olyan összetettebb mozis termékekre is, mint a popcornkóla menükhöz kapcsolt akciós dobozok).

\section{Élelmiszeripari cikkek, italok}

Az olyan - gyermekeket célzó - italok említhetők itt, mint a Micimackó vagy a Tom és Jerry alkoholmentes pezsgők, vagy a különböző aktuális filmekkel összekötött üdítőitalok, édességek vagy a korábban már említett gyorséttermi gyerekmenük a hozzájuk kapcsolt ajándék játékokkal. Sok esetben ezek az ajánlatok önmagukban is további reklámtevékenységet gerjesztenek, amivel természetesen közvetett módon tovább támogatják a hozzájuk tartozó filmet is.

\section{A FILMES MERCHANDISING KIALAKULÁSÁNAK ELŐZMÉNYEI}

A merchandising termékei részben a filmek hagyományos kommunikációs eszközei közé tartoznak, éppúgy, mint a poszterek, az elektronikus sajtóanyagok és állóképek, vagy akár az előzetesek (trailerek, teaserek stb.) (Kerrigan 2010). Másrészt viszont a merchandising fogalma jelentősen túlmutat rajtuk, ahogy az a bevezetőben megemlített szerepköréből következik. Bár a modern merchandising megjelent már a 19. században is (ekkor történt, hogy Adolphus Busch, egy ismert sörgyáros a saját nevét használta fel a címkén, a sör márkájának népszerüsítéséhez); a merchandising alkalmazásának úttörőjeként mégis Walt Disney-t tartják számon, mert ő volt az, aki kifejlesztette és rendszerszerüen alkalmazta. Walt Disney volt az első, aki egy filmes karakterének, Miki egér figurájának felhasználási jogait eladta egy notesz címlapja számára 1929-ben, háromszáz dollárért (Takó 2014). További, talán még jelentősebb lökést adott a későbbi fejlődésnek Kay Kamen 1932-es csatlakozása Walt Disney cégéhez. Ö a következő években ezer fölé duzzasztotta a Miki egér figurát tartalmazó termékek számát, valószínüleg ezért is tartják sokan a „modern licenc atyjának”. Ezt követően a merchandising területén gyors fejlödés indult: a különböző rajzfilmes- és képregényes arculatátvitelek mellett az 50-es években már egyre több szórakoztatóipari-, filmes- és politikai személyiség adta nevét vagy képmását különféle termékekhez, elsősorban ruházatokhoz (egyfajta korai árukapcsolásként).

$\mathrm{Az}$ 1970-es és 80-as években a kiemelt filmjek szereplöire (mint a Star Wars, E.T. vagy Rambo) már egész merchandising-rendszerek épültek. Az innen származó bevételek növekedési üteme is jelentős volt: 1978-ban a Disney merchandising részlege is már 27 millió dolláros bevételt könyvelhetett el, de egy évvel később a Kenner Products a Star Wars szereplöihez kötött termékek értékesítésével már meghaladta a 100 millió dollárt (WIPO, 1994).

A 90-es évek elején a merchandising tevékenység már új szintre lépett: már nem csak kiegészítő bevételként tekintettek rá, hanem a film teljes pénzügyi költségtervezetében is önálló tételként jelent meg. Ennek köszönhetően a stúdióvezetők egyre jövedelmezőbb megállapodásokra törekedtek azon iparági képviselőkkel, akik a licenceiket jól fel tudták használni. A Warner Bros.-hoz tartozó Batman 1989 végi megjelenése például 
nagy merchandising sikernek számított, ugyanis a fekete - Batman logóval ellátott - pólók iránt olyan keresletet teremtett, hogy egy ideig az egész ruhaiparban hiánycikknek számított a fekete színü póló (Marich 2005). Jelentős mérföldkő volt ebben a folyamatban a Disney 1994-es kasszasikere, az Oroszlánkirály is. Ez a rajzfilm 313 millió dolláros belföldi jegybevételt, és emellett 1,5 milliárd dolláros kereskedelmi merchandising bevételt könyvelhetett el. Hasonlóan nagyszerü eredményeket hozott a Harry Potter 1997-es megjelenése, amely a könyvek és a filmek jelentős sikerei mellett természetesen merchandising szempontból is kiemelt figyelmet kapott, különösen a ruházat, valamint a hagyományos- és videojátékok területén. A sorozat alapján még egy vidámparkot is felépítettek az Egyesült Államokban (Canalichio 2018).

Természetesen az eredményes együttmúködések és az egyre növekvő sikerek közé be-becsúsztak időnként komoly bukások is, mint például az 1999-es Star Wars I. rész: Baljós Árnyak, ami alig az egyharmadát tudta teljesíteni a tervezett 3 milliárdos merchandising bevételnek. Ennek következtében a kereskedők némileg óvatosabbá váltak az újabb megállapodásaik kidolgozása során. Így például a már említett Star Wars I. rész sikerének elmaradása után a Hasbro 2003-ban még meghosszabbította ugyan az eredetileg három filmre szóló - akciófigurákra, járművekre és társasjátékokra vonatkozó - szerződését, de a játékgyártó cégek egyre inkább filmenkénti megállapodásokat kezdtek el kötni a korábbi, több filmre szóló nyílt végü elköteleződés helyett (Marich 2005).

\section{A FILMES MERCHANDISING KRITÉRIUMAI}

A merchandising kapcsán felmerülhet a kérdés, hogy mely filmek alkalmasak rá egyáltalán, illetve milyen kritériumoknak kell megfelelniük, hogy élni tudjanak az arculatátvitel eszközeivel. A filmmegjelenések általános trendjeivel összefüggésben elmondható, hogy napjainkban jellemzően a legelőnyösebb pozícióból azok a filmek indulnak, amelyeknek már van valamilyen elözménye, mint például korábbi kapcsolódó filmek, könyvek, képregények vagy más médiumok. Ezt alátámasztja az a tény, hogy a 2016-os év legnagyobb belföldi bevételeit hozó filmjeinek listáján 25 címből mindössze 5 olyan szerepel, amit nem elözött meg valamilyen formátumú előzmény (MPAA 2017).

Erre a jelenségre már Kerrigan is felhívta a figyelmet (2010), amikor megkülönböztette egymástól az úgynevezett ,high concept” nagy- és kisköltségvetésű filmeket. A nagy költségvetésü filmek esetében már a film tervezésének korai fázisában központi szerepet kapnak a különböző kiegészítő termékek, legyen szó termékelhelyezésről vagy a filmhez köthető merchandising termékekről - kiemelve a minél több érintkezési pont szükségességét (Papp-Váry 2014). Miközben az alacsonyabb költségvetésű filmek egyre inkább a független filmkészítés irányába sodródnak, a nagyobb testvéreik egyre inkább a fösodorbeli termékek promóciós eszközeinek tekinthetők. Ahogy egyre nehezebbé válik a filmforgatási költségvetés összeállítása, a szükséges anyagi eszközök biztosítása, várhatóan egyre nagyobb hangsúlyt kap a továbbiakban is a márkázott szórakoztatás.

Fontos lépés volt ebbe az irányba, amikor a filmstúdiók felismerték, hogy már előre értékesíteni tudják a filmhez köthető merchandising jogokat, és az így befolyt összegek hozzá tudnak járulni a film produkciós költségvetéséhez. A Gyürük Ura trilógia esetében is ez történt, ahol ily módon tudták finanszírozni a teljes büdzsé 10\%-át. Ráadásként ezek a termékek hasznosak lehetnek a film reklámozásában is, így a filmre alapozott merchandising sokszor részese lesz azoknak az összevont promóciós kampányoknak, amiket akár hónapokkal a film megjelenése előtt megkezdenek. Sok nagyköltségvetésű film esetében a hozzá köthető merchandising termékek $40 \%$-át már a film megjelenése előtt el is adják (Litwak, 2016). Így biztosítható az ideális merchandising szabály, amikor a film ugyanúgy reklámozza a terméket, ahogy a termék is a filmet. Míg 2002-ben a Pókember filmmel egy időben megjelenő videojáték még kockázatos vállalkozásnak számított, a 2003-as Némó nyomában esetében már eleve úgy tervezték a megjelenést, hogy hetekkel a bemutató előtt megvásárolhatóak legyenek a filmet népszerüsítő játékok és szoftverek, elérve, hogy a fogyasztók már a megismert termékcsalád tagjaként érzékeljék a filmet (Tóth 2015).

Ugyanakkor sok olyan film van, ami limitált merchandising potenciállal rendelkezik. Míg egy újabb Marvel vagy Star Wars film számtalan játékfigurát, posztert és egyéb terméket tud létrehozni és eladni, az olyan filmek számára, mint a Ryan közlegény megmentése vagy az Amerikai szépség sokkal kevesebb lehetőség áll rendelkezésre. A musicalek, mint a Szombat esti láz, a Pomádé vagy a Dirty Dancing kimagasló bevételeket tudnak elérni a filmzene lemezek értékesítése révén, de egy-egy sláger-státuszba lépő zeneszám is sokat tud dobni egy film reklámozásán, így az utóbbi években a zenei videók is kifejezetten fontos marketingeszközökké váltak (Litwak 2016). 
Adott esetben kérdéses lehet az is, hogy milyen plusz tartalmakat tudnak a filmek mellé helyezni. A Szellemirtók eredeti 1984-es megjelenésekor például hiába volt sikeres a mozi pénztáraknál, a hozzá kapcsolódó termékek kereskedelmi forgalma csak a filmen alapuló animációs sorozat megjelenését követően vált jövedelmezővé. Ehhez hasonlóan, amikor a Warner Bros. merchandising partnereket keresett a Batman: Kezdödik! 2005-ös megjelenéséhez, az értékesítési ajánlatában egy új Batman animációs sorozat elindítása is szerepelt (Marich 2013).

A megtérülő merchandising szempontjából egyébként a magasabb korhatár-besorolást elkerülő családi- és fiatalabb korcsoportokat célzó filmek vannak a legkedvezőbb helyzetben (Marich 2013). Az ilyen filmekhez kapcsolható játékok és videojátékok általánosságban is kiteszik a merchandising termékek közel 50\%-át (Tóth 2015). A helyzet már bonyolultabbá válik az olyan esetekben, ahol a kapcsolt - azonos címü vagy azonos brandhez tartozó - termékek a „gazdafilmtől” eltérő besorolásban részesülnek. Ilyen helyzetre lehet példa egy olyan videojáték vagy filmzenei $\mathrm{CD}$, amely már elérhető a tinédzser korosztálynak is, holott egy eredetileg felnőtt korhatáros filmhez kapcsolódik (FTC 2004).

Mindeközben arra is van példa, hogy az arculatátvitelre tökéletes filmek kimagasló sikerei már negatívan hatnak az ipar licenciákat forgalmazó egyéb szereplöire. Ez történt például a Disney 2013-as sikerfilmje, a Jégvarázs esetében is. A nemzetközi Licensing Industry Merchandisers' Association (LIMA) jelentése szerint a film 1,3 milliárd dolláros forgalmazási bevételt ért el világszerte, ráadásul jelentős részesedést is szerzett a 2013-2014. évi licenc- és jogdíjbevételekből. Ez komoly fejtörést okozott a többi arculatátvitelre szakosodott cégnek, mivel a kereskedők előszeretettel töltötték meg a polcaikat a Jégvarázs-hoz kapcsolódó termékekkel, kiszorítva ezzel más szintén vonzó licencekre alapozott - termékeket. Az ily módon „kifárasztott” márkák és túltelített megjelenések egy általános negatív trendet jelentenek a merchandising területén, ahogy azt a LIMA egyik munkatársa megfogalmazta (Robehmed 2015).

Bármennyire is kiemelkedő a Jégvarázs berobbanása a piacra, még mindig nem ez tekinthető a Disney legjövedelmezőbb címének - igaz, még nem volt alkalma teljesen kiteljesedni, mint a társainak, mivel az alapfilmen kívül ez idáig csak két rövidfilmet kapcsoltak hozzá, míg az egész estés folytatást csak 2019 végére tüzték ki. Ezzel az teljesítménnyel a - messze a többi fölé tornyosuló - Star Wars büszkélkedhet, ahogy ez látható az 1. ábrán is.

\section{1. ábra: Éves merchandising bevételek 2015-ben (Mrd. dollárban)}

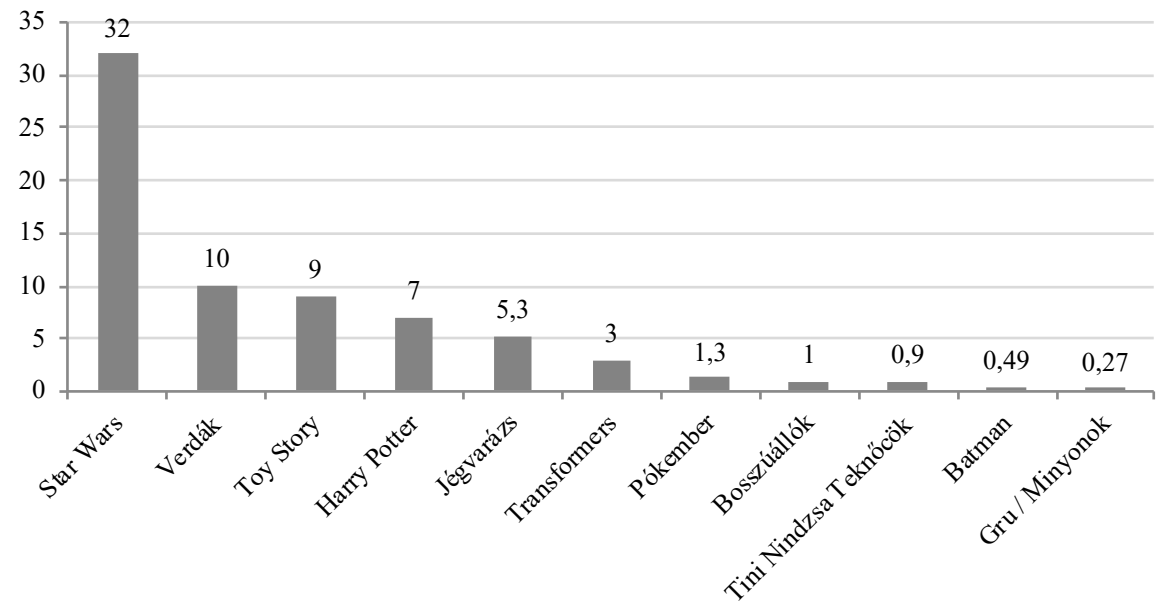

Forrás: STATISTA (2018) alapján saját szerkesztés 
A legfrissebb eredmények tükrében azonban elmondható, hogy még a kimagasló Star Wars helyzete sem megingathatatlan, mivel a 2017-es eladásai gyengébben teljesítettek, mint az előző évben, hiába jelent meg év végén az új számozott epizód. A BMO Capital elemző cég képviselöi a Star Wars merchandising eredményeinek elmaradását vizsgálva többek között a Jégvarázs kapcsán már említett márka kifáradását említették (itt bosszulja meg magát, hogy a korábbi több évet felölelö ciklusok helyett immáron évente várható egy-egy újabb Star Wars univerzumhoz köthető film). Emellett az okok között kiemelték a szórakoztató médiatartalmak általános túláradását, valamint a különböző filmsorozatok közti egyre kiélezettebb versenyt (Cavanaugh 2018).

\section{A MERCHANDISING FOGYASZTÓI MEGÍTÉLÉSE}

A szórakoztatóiparnak állandóan meg kell újulnia, éppen úgy, ahogy az emberek ízlése is folyamatosan változik. A populáris kultúrát folyamatosan külső befolyások érik, melyek hatása tetten érhető a létrehozott szórakoztató tartalmakban és azok népszerüsítési módszereiben egyaránt. Mindez természetesen kölcsönös kapcsolatban áll a fogyasztói megítéléssel, ami azt is meghatározza, hogy milyen típusú termékek jelenhetnek meg a kereskedelmi üzletek polcain. Ami még elfogadható szórakozási forma volt tegnap, mára már lehet, hogy elfogadhatatlanná vált. Így például annak idején az első Rambo filmek nyomán a játékboltok polcait természetes módon árasztották el a játékfegyverek, míg ugyanezek a John Rambo 2008-as megjelenésekor már komoly szülői felháborodást váltottak ki (Simon 2010).

Az viszont biztos, hogy a popkultúra erősen támaszkodik a filmekre, ezért a mozihoz köthető merchandising termékek fogyasztásának korábban soha nem tapasztalt szintje alakult ki, ami egyúttal a személyiség önkifejezési lehetőségévé is vált a fogyasztók számára. A valaha még szubkultúrának nevezett rajongói magatartás mára keresett és divatos fogyasztói attitüddé változott, a filmes merchandising termékekkel pedig egyre gyakrabban találkozhatunk a lakáskultúra magazinok és blogok oldalain. Ezt a hatást erősíti meg az is, hogy az egykoron megvetett ,geek” (magyarul gyakran „kocka” fordításban) szereplőtípus egyre nagyobb szerepekhez jut mind a nagyköltségvetésủ filmek, mind a közismert sorozatok esetében. Az ilyen merchandising termékek tulajdonlása az egyéniség kifejezésének egyik fontos eszközévé vált, ami közeli kapcsolatban áll a geek szubkultúra egyre szélesebb elterjedésével (Tóth 2015).

\section{KÖVETKEZTETÉSEK}

Általánosan összefoglalva azt mondhatjuk, hogy az elmúlt évek során a merchandising-ot folyamatosan növekedő érdeklődés övezte. Így például 2017ben több mint 20 film rendelkezett jelentős mértékủ arculatátvitellel és így komoly merchandising bevétellel, tíz évvel korábban még fele ennyi sem volt. Ez a növekedés annak ellenére következett be, hogy ezen időszak alatt az Egyesült Államokban a mozik látogatottsága összességében 14\%-al csökkent (Townsend \& Palmeri 2018).

A merchandising alakulásában meghatározó szerepe van a digitális technológia fejlődésének, éppen úgy, ahogy a világ gazdasági és társadalmi folyamataiban általában. Elsősorban ez alakítja a fogyasztók szórakozási formáit, ráadásul a vásárlási szokásaikra is egyre nagyobb hatást gyakorol, így a merchandising termékek egyre nagyobb részét értékesítik digitálisan. Ezt a tényt az is bizonyítja, hogy a Disney egybeolvasztotta a fogyasztói- és az interaktív termékekkel foglalkozó részlegeit, tovább szúkítve a határvonalat a szórakoztatás és a játék kategóriák között. (A nyomtatott- és zenei tartalmak, a videojátékok, illetve a szoftverek/alkalmazások disztribúciójának többségét digitálisan oldják meg és ezek a teljes merchandising értékesítés $12 \%$-át teszik ki.) A digitális szegmensek növekedése többek között azt is eredményezte, hogy világszerte is egyre több helyen váltak elérhetővé a licencen alapuló termékek (Canalichio 2018).

A Disney a legnagyobb fogyasztói termékekhez köthető licenctulajdonos, messze kimagaslóan a második helyezett előtt, így a legtöbb termékkategória szempontjából ő diktálja az iramot a partnerei számára. Sikereit látva egyre több stúdió alkalmazza a merchandising-ot, ám nekik még van mit tanulniuk, míg a Disney már számításba tudja venni egy-egy újabb beruházás minden bevételt hozó vetületét: a licenc alapú merchandising-ot, a termékelhelyezést, az on-demand jellegü tartalommegosztást vagy akár a vidámparkokat - mint tette ezt a Lucasfilm, a Marvel Entertainment vagy legutóbb a Fox felvásárlásakor (Canalichio 2018).

Mindeközben a bizalom már nem feltétlen és teljes körü - és ezt a legfrissebb visszaesések is várhatóan tovább gyengítik majd: a hosszabb filmsorozatok melletti elköteleződés helyett a kereskedelmi cégek ma már az egy-egy filmre szóló megállapodásokat helyezik előtérbe, másrészt az elmúlt évtizedben elkezdték áthelyezni a hangsúlyt a 
filmek „második vonalbeli” megjelenésére, vagyis a DVD/Bluray kiadásokra, ami általában kettő-négy hónappal a szélesvásznú bemutató után történik. A házimozi vonzerejét elsősorban az adja, hogy a film népszerüségét már megalapozta a mozis bemutató, így a merchandising-ot nyújtó cégek sikeresen fel tudják mérni a filmhez köthető termékek iránti keresletet, és a kereskedelmi boltok polcain még az árukapcsolást is jobban meg tudják oldani (Marich, 2013). Az is egyre behatároltabbá válik, hogy melyek azok a nagyköltségvetésủ filmtervek, amelyek egyáltalán zöld utat kaphatnak. A befektetői elvárások az elsődleges (mozi) és másodlagos (otthoni) terjesztés bevételei mellett immáron kiterjednek a merchandising termékek utáni bevételekre is (Tóth 2015). Ezen logika alapján viszont aggodalomra adhat okot, hogy a közönség kisebb és speciálisabb csoportjainak készült termékek már sokkal nagyobb kockázatot jelentenek, és ez további nyomást helyez a nagyobb stúdiókra, hogy a folytatások és újrakezdések jelentette biztonsági játékot folytassák az elkövetkező évek során.

\section{HIVATKOZÁSOK}

Barta, B. - Szücs, R. S. (2015), „Reklámozás, szlogen és szuperhősök - A gyermekek meggyőzésének eszközei." Táblálkozásmarketing, 2 2, 47-57, DOI: https://doi.org/10.20494/tm/2/2/4

Bereczkiné Farkas, E. (2008), „Merchandising”. In. Dankó L. (szerk.) Értékesítés - ösztönzés. Miskolc: Pro Marketing Miskolc Egyesület, 252-81

Canalichio, P. (2018), Expand Grow Thrive, Bingley: Emerald, DOI: https://doi. org $/ 10.1108 / 9781787437814$

Cavanaugh, P. (2018), Star Wars Toys Sales Fall With ,The Last Jedi', http://comicbook.com/ starwars/2018/01/18/star-wars-the-last-jeditoys-drop-disappointment/ Letöltve: 2018.01.21

Federal Trade Comission (2004), Marketing Violent Entertainment to Children: A Report to Congress, https://www.ftc.gov/sites/default/ files/documents/reports/marketing-violent-entertainment-children-fourth-follow-review-industry-practices-motion-picture/040708kidsviolencerpt.pdf Letöltve: 2018.02.16

Kerrigan, F. (2010), Film Marketing. Oxford: Elsevier DOI: https://doi.org/10.1016/b978-0-75068683-9.10011-0

Litwak, M. (2016), Dealmaking in the Film \& Television Industry, 4/e. Los Angeles CA: Silman-James Press
Marich, R. (2005), Marketing to Moviegoers: A Handbook of Strategies Used by Major Studios and Independents. Burlington, MA: Focal Press DOI: https://doi.org/10.4324/9780080491776

Marich, R. (2013), Marketing to Moviegoers: A Handbook of Strategies and Tactics. Carbondale, IL: Southern Illinois University Press

Motion Picture Association of America, Inc. (2017), Theatrical Market Statistics 2016. Sherman Oaks, CA: MPAA. https://www.mpaa.org/wp-content/ uploads/2017/03/MPAA-Theatrical-Market-Statistics-2016 Final.pdf Letöltve: 2017.12.10

Papp-Váry, Á. (2014), Márkázott szórakoztatás. Budapest: Akadémiai Kiadó DOI: $10.1556 / 9789630597913$

Robehmed, N. (2015), The ,Frozen' Effect: When Disney's Movie Merchandising Is Too Much, https://www.forbes.com/sites/natalierobehmed/2015/07/28/the-frozen-effect-when-disneys-movie-merchandising-is-too-much/ Letöltve: 2018.02.10

Schreiber, A. (2009), „Szemmagasság (Marketing és a gyerekek)", Filmvilág, 52 7, 44-45

Simon, D. (2017), „Character and Entertainment Licensing". In. Battersby, G. J., Grimes, C. W. (Eds.) Licensing Update 2017 Edition. New York, NY: Wolters Kluwer

Statista (2018), „Leading Hollywood movies based on merchandise sales revenue as of January 2016 (in billion U.S. dollars)." https://www.statista. com/statistics/519093/leading-movies-based-onmerchandise-sales/ Letöltve: 2018.02.10

Takó S. (2014), „A filmkészítés folyamatát övező polgári jogi kérdések Magyarországon és az Egyesült Államokban, különös tekintettel a szerzői jogra.” Iparjogvédelmi és Szerzői Jogi Szemle, 9 1, 54-5

Tóth Z. J. (2015), „A hollywoodi film háttéripara. Merchandising és forgalmazás a Star Warstól napjainkig." Apertúra, tavasz-nyár, http:// uj.apertura.hu/2015/tavasz-nyar/toth-a-hollywoodi-film-hatteripara-merchandising-es-forgalmazas-a-star-warstol-napjainkig/ Letöltve: 2018.02.18

Townsend, M., Palmeri, C. (2018), „'Star Wars' Toy Sales Fall in 2017 as Movie-Tie Fatigue Sets In." https://www.bloomberg.com/news/ articles/2018-01-18/-star-wars-toy-sales-fallin-2017-as-movie-tie-fatigue-sets-in Elérve 2018.01.21

World Intellectual Property Organization (1994), Character Merchandising. Geneva: WIPO. http://www.wipo.int/export/sites/www/copyright/en/activities/pdf/wo_inf_108.pdf Letöltve: 2018.02.18 
Horváth Ádám tanársegéd horvath.adam.benedek@gtk.szie.hu

Gyenge Balázs PhD, egyetemi docens gyenge.balazs.mark@gtk.szie.hu

Szent István Egyetem Marketing Módszertani Tanszék

\section{Movie merchandising - a literature study of its various forms, application criteria and history}

\section{THE AIMS OF THE PAPER}

Nowadays we may find that the brands and audiovisual elements of movies are not only present on the screens of movie theatres but in the form of various accompanying products appearing in retail stores as well. This phenomenon can also be defined as ,image transfer", when distinct products and services are linked together with other events, in this case with the release of movies (thus creating relevancy between the two).

This paper aims to explore the main characteristics of movie related merchandising and to study the various kinds of image transfer used by movies. It also aims to describe the role of merchandising among the other tools that are available to promote the a new movie's release, and to find out what the possible criteria could be that a certain movie has to meet in order to make merchandising applicable as a promotional tool, what the main differences are between newly introduced intellectual properties and already existing brands of movie series. Finally it seeks to find out how the consumers' perception may have changed over time regarding the products and services involved.

\section{METHODOLOGY}

The methodology used in the study was to conduct literature review, summarizing the main theoretical approaches and contexts, and exploring the results of major related researches that have taken place in the recent years.

\section{MOST IMPORTANT RESULTS}

Among the results, we can highlight the growing interest in merchandising and especially the activities carried out by Disney, which is considered to be the absolute leader of this area. It should be noted however, that due to some growing uncertainty, the timing of merchandising is often pushed towards the home releases.

\section{RECOMMENDATIONS}

Our suggestion is to conduct an empirical research that could examine all aspects of cross-promotion between movies and related merchandising, as well as digital solutions that have gained ground in recent years.

Keywords: merchandising, movie consumption, consumer behavior 